\title{
DYNAMICS OF NITROGEN AND PHOSPHORUS FORMS CONTENT IN DOJLIDY RETENTION RESERVOIR
}

\author{
Katarzyna Oszczapińska', Iwona Skoczko' ${ }^{1}$ Joanna Szczykowska' ${ }^{1}$ \\ Department of Technology in Engineering and Environmental Protection, Bialystok University of Technology, \\ Wiejska St. 45E, 15-351 Bialystok, Poland, e-mail: k.oszczapinska@doktoranci.pb.edu.pl, i.skoczko@pb.edu.pl, \\ j.szczykowska@pb.edu.pl
}

Received: 2016.07 .01

Accepted: 2016.10 .23

Published: 2017.01 .01

\begin{abstract}
The Dojlidy Ponds, which include Dojlidy water dam, are located within Bialystok city limits in Podlasie area, Poland. The reservoir with a water surface of 34 ha and average depth of $1.75 \mathrm{~m}$ was constructed in 1962 as a result of Biala River damming. The researches were conducted in July, October and December 2014 as well as in March 2015. Each time five test samples were collected from spots located along the reservoir. Water samples were tested for the presence of ammonia nitrogen, nitrite nitrogen, organic nitrogen, phosphates and organic phosphorus. The values of nutrient indicators exhibited high variability during the study period. The highest concentration of nitrite and nitrate nitrogen were observed in July, while the lowest in October nitrite nitrogen, and in December - nitrate nitrogen. Different situation was observed after the analysis of phosphorus forms - the highest concentrations of organic phosphorus and phosphates were observed in December and the lowest in July. Relatively high concentrations of nitrogen and phosphorus forms identified in water samples were most likely caused by tributaries, due to the pollution from the reservoir catchment. Technical parameters of the object and location of the reservoir have undoubtedly an impact on the tested parameters contents.
\end{abstract}

Keywords: water pollution, nitrate nitrogen, ammonia nitrogen, phosphates

\section{INTRODUCTION}

Estimated Polish water resources are below the European average. Water is the most vital compound for living organisms, including humans. Therefore, it seems to be the priority to maintain the status of water at the highest possible level of quantity and quality. The needs of the national economy are mostly covered by surface water. The solution can be construction of retention reservoirs, the current number of which in Poland does not give a full ability to protect against flood, drought, and does not guarantee adequate water supply. Therefore, it is important to check the status of reservoirs already created. This may include biological examination of water.

A large impact on the deterioration of the surface water resources is exerted by nitrogen and phosphorus compounds that penetrate the watercourses along with municipal wastewater. It was found that $65 \%$ of nitrogen compounds are discharged into the rivers as a the result of surface runoff from agricultural lands. It is estimated, that annual losses of phosphates due to elution are at the level of about 0.1-5\% [Dobrzańska et al. 2008; Grabińska et al. 2005; Kiryluk, Rauba 2011]. A certain amount of phosphate may origin from weathering and dissolution of minerals, soil erosion, and precipitation. However, the impact of these factors is not as important as anthropogenic pollution [Grabińska 2005; Skonieczek 2011; Szymczyk 2011].

Polish law provides concentration limits for total nitrogen and total phosphorus but it is important to observe and analyze changes in the content of individual nutrient forms. 
The aim of the study was to evaluate seasonal changes in the concentration of selected nutrient indicator forms in the Dojlidy reservoir.

\section{RESEARCH METHODS}

Dojlidy reservoir, located in Podlasie area in the south-east of Bialystok, is part of Dojlidy Ponds. It was built in 1962 by damming the Biala River. Previously, there were two other reservoirs named Plażowy and Cygański in this place. The total capacity of the reservoir is about 597040 $\mathrm{m}^{3}$, average depth $1.75 \mathrm{~m}$ with water surface 34 ha [Kluczko 2014, Rola 2002]. The Dojlidy water body is powered by the Biala River with a catchment area of $14.5 \mathrm{~km}^{2}$ on its $2+750$ kilometer and by nameless watercourse from the Upper Dojlidy with a catchment area of $2.6 \mathrm{~km}^{2}$ [Kluczko 2014].

The research object is used as a swimming pool, but in the period of the study it was excluded from this type of use as a result of the modification works made by Water Sports Centre "Dojlidy". It is also a place for extensive, non-commercial fish farming. In addition, the reservoir has the task of regulating water surface runoff [Tyszewski 2009]. Surface water samples from five sites along Dojlidy reservoir were collected on four separate dates (July 2014, October 2014, December 2014 and March 2015). The sampling points were distributed in specific areas within Dojlidy to allow the observation of changes dynamics in the ecological status of the object.

The first point was located near the Biala River flow into the reservoir. The second point included central, coastal part of the object. The third point was located nearby the bridge on the beach. The fourth point was the place of water outflow over the front dam, while the fifth point was on the Biala River, behind the reservoir (Figure 1).
The water samples were collected from a depth of about $0.4 \mathrm{~m}$ to the PET bottles with a capacity of $1.5 \mathrm{dm}^{3}$. The water samples were analyzed for the presence of the following indicators: ammonium nitrogen, nitrite nitrogen, nitrate nitrogen, organic nitrogen, phosphates, and organic phosphorus. Different parameters were determined by a UV-VIS spectrometry according to the following methods [HACH 1992]:

- Ammonia nitrogen - direct nesslerization method PN-C-04576-4:1994P;

- Nitrite nitrogen - the NitriVer ${ }^{\circledR} 3$ diazotization method, $\mathrm{HACH}{ }^{\circledR}$ Company;

- Nitrate nitrogen - the NitraVer ${ }^{\circledR} 5$ cadmium reduction method, $\mathrm{HACH}{ }^{\circledR}$ Company;

- Phosphates - the PhosVer ${ }^{\circledR} 3$ ascorbic acid method, $\mathrm{HACH}{ }^{\circledR}$ Company;

- Organic nitrogen and organic phosphorus calculation methods.

Moreover, during the study period, the weather conditions, that are presented in Table 1, were recorded.

\section{RESULTS AND DISCUSSION}

During the study period, the values of nutrient indicators exhibited high variability. The results of the analysis are given in Table 2.

The highest concentration of ammonia nitrogen was observed in December, while the lowest in July. Likewise, the concentration of phosphates and organic phosphorus reached its maximum in December and minimum in July. However, different trends were noticed about nitric, nitrate, and organic nitrogen.

Concentration of ammonia nitrogen ranged between $0.046 \mathrm{~g} \mathrm{~N} / \mathrm{m}^{3}$ and $0.583 \mathrm{~g} \mathrm{~N} / \mathrm{m}^{3}$. In general, the highest concentration characterized the fifth point except for the July measurement. Large

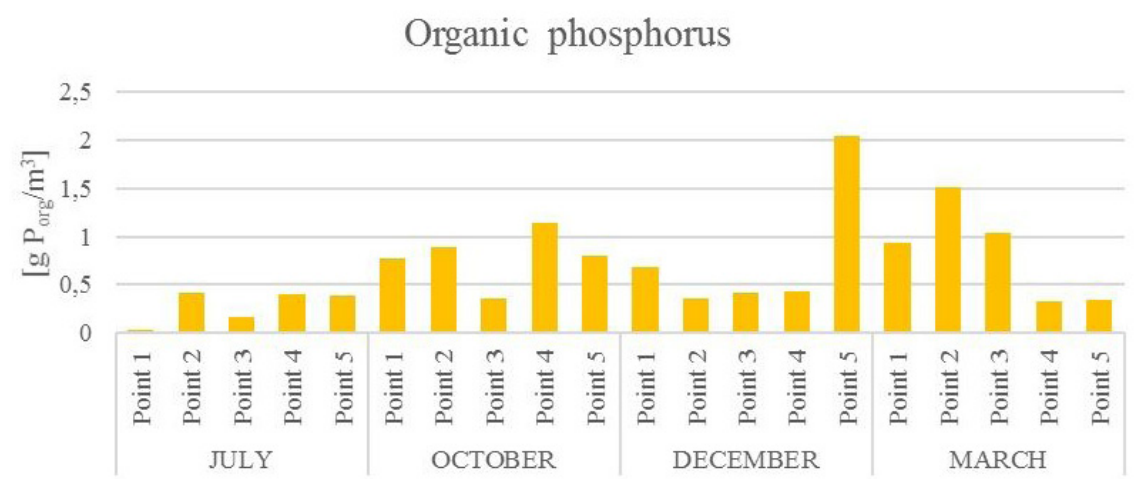

Figure 1. Location of control points within Dojlidy reservoir [geoportal.gov.pl] 
Table 1. Weather conditions in Dojlidy reservoir during the water sampling carried out in 2014/2015 [pogoda.interia.pl]

\begin{tabular}{|c|c|c|c|c|c|}
\hline Sampling date & $\begin{array}{c}\text { Temperature } \\
{\left[{ }^{\circ} \mathrm{C}\right]}\end{array}$ & Cloudiness & Rainfall & Wind speed & Attentions \\
\hline July 2014 & 21 & $\begin{array}{l}\text { Considerable } \\
\text { cloudy }\end{array}$ & None & $11 \mathrm{kph}$ & $\begin{array}{l}\text { Intensive rainfall the day before } \\
\text { sampling }\end{array}$ \\
\hline October 2014 & 12 & Mostly cloudy & None & $15 \mathrm{kph}$ & $\begin{array}{l}\text { Showers of rain and snow the day } \\
\text { before sampling; foggy }\end{array}$ \\
\hline December 2014 & -3 & $\begin{array}{l}\text { Considerable } \\
\text { cloudy }\end{array}$ & None & $4 \mathrm{kph}$ & $\begin{array}{l}10 \mathrm{~cm} \text { ice cover on the surface of the } \\
\text { reservoir }\end{array}$ \\
\hline March 2015 & 6 & None & None & $20 \mathrm{kph}$ & $\begin{array}{c}\text { Big wave of water caused by strong } \\
\text { wind }\end{array}$ \\
\hline
\end{tabular}

Table 2. Water quality parameters during the period of researches and average concentrations

\begin{tabular}{|c|c|c|c|c|c|c|c|}
\hline Indicator & Point & $\begin{array}{c}\text { Ammonia nitrogen } \\
\mathrm{g} \mathrm{N} \times \mathrm{m}^{-3}\end{array}$ & $\begin{array}{c}\text { Nitrite } \\
\text { nitrogen } \\
\mathrm{g} \mathrm{N} \times \mathrm{m}^{-3}\end{array}$ & $\begin{array}{l}\text { Nitrate } \\
\text { nitrogen } \\
\mathrm{g} \mathrm{N} \times \mathrm{m}^{-3}\end{array}$ & $\begin{array}{l}\text { Organic } \\
\text { nitrogen } \\
\mathrm{g} \mathrm{N} \times \mathrm{m}^{-3}\end{array}$ & $\begin{array}{l}\text { Phosphates } \\
\mathrm{g} \mathrm{PO}_{4} \times \mathrm{m}^{-3}\end{array}$ & $\begin{array}{c}\text { Organic } \\
\text { phosphorus } \\
{\mathrm{g} \mathrm{P} \times \mathrm{m}^{-3}}^{-3}\end{array}$ \\
\hline \multirow{5}{*}{ July } & 1. & 0.225 & $\underline{0.0226}$ & 3.6 & 3.03 & 1.72 & $\underline{0.03}$ \\
\hline & 2. & 0.121 & 0.0037 & 2.1 & 1.25 & 0.84 & 0.42 \\
\hline & 3. & $\underline{0.046}^{1}$ & 0.0062 & 2.3 & 1.83 & 0.95 & 0.17 \\
\hline & 4. & 0.306 & 0.0150 & $\underline{4.4}$ & 3.57 & 1.13 & 0.40 \\
\hline & 5. & 0.086 & 0.0046 & 1.9 & 2.79 & $\underline{0.71}$ & 0.38 \\
\hline \multirow{5}{*}{ October } & 1. & 0.259 & 0.0185 & 0.7 & 0.12 & 5.52 & 0.77 \\
\hline & 2. & 0.124 & 0.0040 & 0.6 & 1.38 & 1.72 & 0.89 \\
\hline & 3. & 0.257 & $\underline{0.0018}$ & 0.4 & 0.62 & 2.14 & 0.36 \\
\hline & 4. & 0.078 & 0.0036 & 0.8 & 0.67 & 3.25 & 1.14 \\
\hline & 5. & 0.345 & 0.0021 & 0.9 & 0.28 & 1.47 & 0.80 \\
\hline \multirow{5}{*}{ December } & 1. & 0.191 & 0.0187 & 2.3 & 0.31 & 5.59 & 0.68 \\
\hline & 2. & 0.087 & 0.0061 & 0.4 & 1.29 & 5.19 & 0.35 \\
\hline & 3. & 0.154 & 0.0021 & 0.3 & 0.72 & 4.86 & 0.41 \\
\hline & 4. & 0.095 & 0.0048 & 0.3 & 0.15 & 4.94 & 0.43 \\
\hline & 5. & $\underline{0.583}$ & 0.0075 & 0.4 & $\underline{0.04}$ & 4.31 & $\underline{2.05}$ \\
\hline \multirow{5}{*}{ March } & 1. & 0.168 & 0.0167 & 1.2 & $\underline{5.96}$ & 4.78 & 0.94 \\
\hline & 2. & 0.079 & 0.0065 & 0.4 & 1.17 & 4.04 & 1.51 \\
\hline & 3. & 0.143 & 0.0093 & 0.4 & 2.48 & 3.92 & 1.03 \\
\hline & 4. & 0.106 & 0.0067 & 0.4 & 0.52 & 4.22 & 0.33 \\
\hline & 5. & 0.533 & 0.0064 & $\underline{0.1}$ & 1.59 & 5.10 & 0.34 \\
\hline \multicolumn{2}{|c|}{ Average } & 0.199 & 0.0083 & 1.2 & 1.49 & 3.32 & 0.67 \\
\hline
\end{tabular}

${ }^{1}$ Bold and underlined extreme concentrations

amounts of analyzed indicators were also determined in the inflow to the Dojlidy (Figure 2). In the water samples taken from the reservoir, the ammonia nitrogen content was within the range of $0.046-0.306 \mathrm{~g} \mathrm{~N} / \mathrm{m}^{3}$ and the lowest concentration was determined in December. During the study conducted in autumn, winter and spring, a significant increase in the concentration of ammonia nitrogen in the Biala River at the outflow of the water reservoir was alleged. In terms of the ammonia nitrogen content, Dojlidy reservoir was a source of pollution for the Biala River. Higher concentration of ammonia nitrogen could be the result of natural fertilizers in the autumn and before grazing cattle on pasture in early May [Adams, McAllister 1975; Fortyma, Duer 2006; Pietrzak, Sapek 1998]. $90 \%$ of ammonia emission is from agricultural sources (livestock and fertilizer) according to the studies conducted in the United States [Battye et al. 1994].

The highest concentrations of nitrite nitrogen were observed in samples collected from the Biala River before flowing into the pond. Each time, they were higher than concentrations in the other sampling points and their contents ranged within $0.0167-0.0226 \mathrm{~g} \mathrm{~N}-\mathrm{NO}_{2} / \mathrm{m}^{3}$ (Figure 3). Therefore, the Biala River catchment area was a substantial source of nitrite nitrogen pollution. 


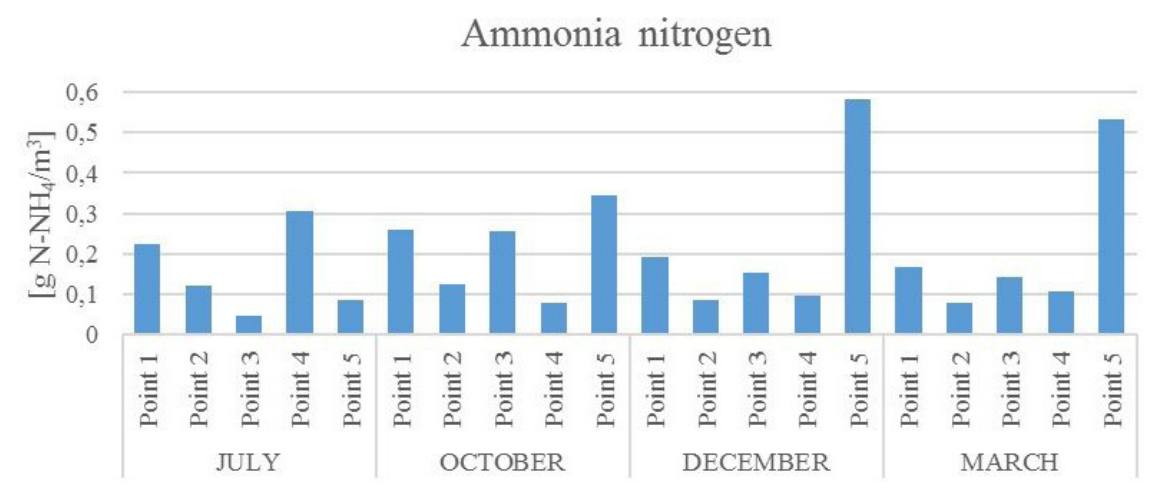

Figure 2. Seasonal changes in ammonia nitrogen concentration in sampling points during the researches

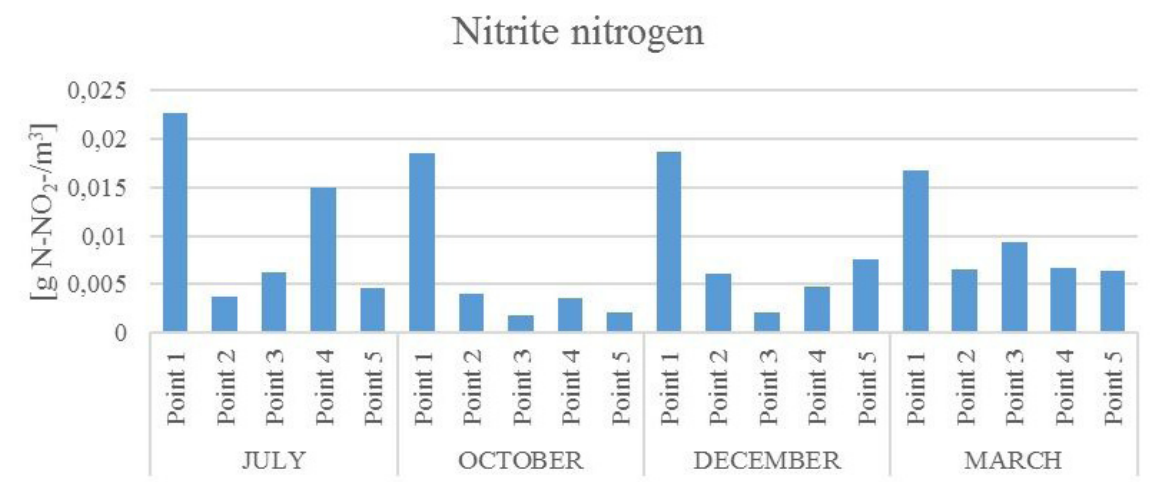

Figure 3. Seasonal changes in nitrite nitrogen concentration in sampling points during the researches

The Dojlidy reservoir did not exhibit the selfclearage ability after analyzing the distribution of results. Increasing concentration of nitrite nitrogen with the direct water flow proves this, particularly during the research carried out in July and December.

The result of the nitrate nitrogen concentration studies was explicitly higher content in July, especially in the fourth sampling point with

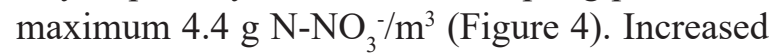
nitrate nitrogen amount during summer measurements could be caused by runoff from agricultural areas after heavy rain the day before. Similar observations were made during the study led by Rawicki and Siwek [2014] and Sapek [2011]. In their research objects the amount of nitrate nitrogen has risen in July and August. This could cause the surface runoff after intensive rainfalls [Zdanowicz 2009]. In turn, lower concentration during autumn, winter and spring tests may be due to the processes of nitrates to nitrites reduction as well as free nitrogen form (Table 1) [Gundersen, Rasmussen 1990]. Moreover, low concentration of ammonia and nitrite nitrogen, while high nitrate content, may indicate a water pollution remote in time [Koszelnik 2009, Koszelnik et al. 2014].

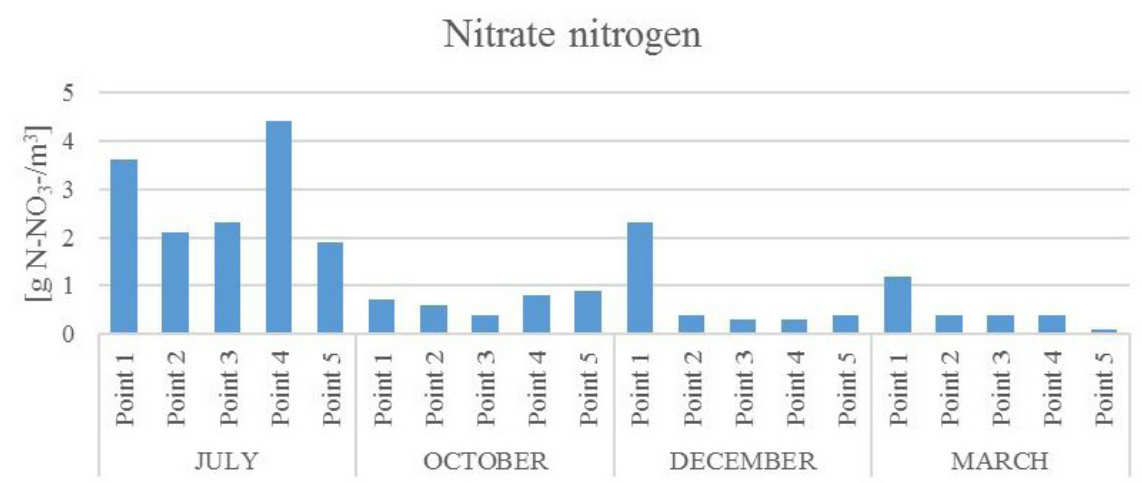

Figure 4. Seasonal changes in nitrate nitrogen concentration in sampling points during the researches 
Similar to nitrates, the highest concentration of organic nitrogen was observed in July, while lower in October and December. Exceptionally in the first sampling point in March, the highest concentration in the Biala River $-5.96 \mathrm{~N}_{\text {org }} \mathrm{g} / \mathrm{m}^{3}$ was recorded. Grabińska [2005] confirmed that during spring thaws, the concentration of organic nitrogen was increased in the rivers. March and July, like a growing season, were characterized by higher organic nitrogen concentrations. It is associated with water biomass growth, which after that usually breaks down into other forms of nitrogen (Figure 5).

The Dojlidy pond is characterized by high phosphates concentration, especially during winter and spring. The lowest phosphates concentrations were observed in July. Then, the content in the reservoir did not exceed $1.13 \mathrm{mg} \mathrm{PO}_{4}^{3-} / \mathrm{dm}^{3}$, while in the Biala River the concentration of phosphates in influent water was $1.7 \mathrm{mg} \mathrm{PO}_{4}^{3-}$ $\mathrm{dm}^{3}$. Slightly higher levels of phosphates, within the range of $1.47-5.52 \mathrm{mg} \mathrm{PO}_{4}^{3-} / \mathrm{dm}^{3}$, were determined in water flowing into the reservoir in October. On the other hand, studies conducted in December 2014 and March 2015 showed much higher concentrations within the range of $3.92-5.59 \mathrm{mg} \mathrm{PO}_{4}^{3-} / \mathrm{dm}^{3}$.
There were no apparent self-clearage abilities in regard to phosphates in the reservoir. Possible internal water enrichment in phosphates was particularly evident in October, when their concentration gradually increased along with water flow through the object. During the study, we noticed marked seasonal changes in the concentration of phosphates in the Dojlidy reservoir (Figure 6). As the phosphorus in the form of ions $\mathrm{PO}_{4}^{3-}$ is taken up by plants, the concentration of phosphates in July is relatively low. In October, aquatic organisms, which during the growing season have taken up considerable amounts of phosphorus, were necrosing and giving it then just in a form of orthophosphate. High concentration of analyzed indicator was observed in December and March as a result of autumn biochemical changes [Szczykowska et al. 2015b; Wetzel 2001]. It was also aided by the circulation of autumn and spring waters and anaerobic conditions prevailing under the $10 \mathrm{~cm}$ thickness ice layer in December (Table 1). As the main external source of phosphates can be regarded the surface runoff from nearby peat bogs, which also favored precipitation facilitating the leaching of organic matter from the soil. In addition, a possible source of phosphate pollution may be the phosphoric fertilizers used in the di-

\section{Organic nitrogen}

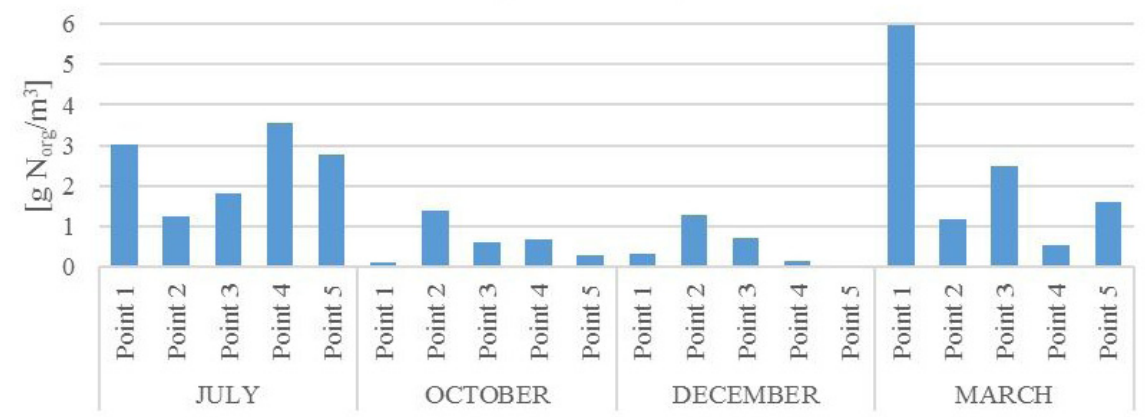

Figure 5. Seasonal changes in organic nitrogen concentration in sampling points during the researches

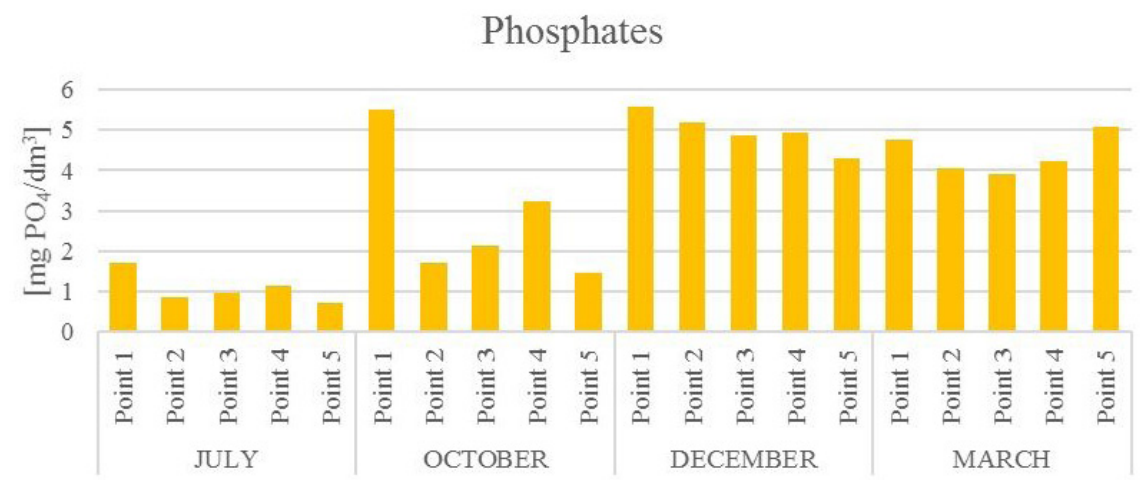

Figure 6. Seasonal changes in phosphates concentration in sampling points during the researches 
rect catchment, as well as tributaries of sewage, abundant in phosphates derived from the use of household laundry detergents [Adamczyk, Jachimowski 2013; OECD 2003].

Like in the case of phosphates, also organic phosphorus studies have seasonal variations in concentration. The lowest values not exceeding $0.42 \mathrm{mg} \mathrm{P} / \mathrm{dm}^{3}$ were recorded in July, which is associated with the most likely distribution of phosphorus in organic form by aquatic organisms. Relatively low concentrations were also obtained during tests in December, when the necrosed organisms were deposited in sediments [Strzelec et al. 2010; Zhou et al. 2000]. The ice layer on the surface of the reservoir at the same time prevented the movement of water masses and migration of organic phosphorus, thus subsurface waters indicated its smaller quantities. After that, during autumn and spring water circulation the concentrations of organic phosphorus were higher [Szczykowska et al. 2015a]. This phenomenon was so much better visible because of low average water depth - only 1.75 m [Kluczko 2014].

\section{CONCLUSIONS}

1. All of the analyzed indicators exhibited seasonal concentration changes. Phosphorus forms reached highest concentrations during winter studies and lowest during summer measurements. Nitrogen forms, except of ammonia nitrogen, reached their maximum concentrations during summer researches and minimum concentrations in autumn (nitrites) and winter (nitrates and organic nitrogen).

2. Prolonged water retention could lead to the accumulation of organic matter on the bottom of the reservoir, which may indicate high levels of nitrogen and organic phosphorus marked es- pecially during spring and autumn determinations, while water micturition.

3. The Dojlidy reservoir showed no self-purification ability in relation to all of the indicated parameters.

4. The chemical composition of water samples shows that the catchment area is possible main source of Dojlidy reservoir pollution. Increased nutrients concentrations during spring study have been the result of surface runoff from agricultural area.

5. Due to high concentrations of nitrogen and phosphorus forms, the research object is susceptible to eutrophication.

\section{REFERENCES}

1. Adamczyk W., Jachimowski A. 2013. Impact of biogenic components on quality and eutrophication od flowing Surface waters constituting the source of drinking water for the city of Kraków. Food. Science. Technology. Quality, 6(91), 175 190. (In Polish)

2. Adams S. N., McAllister J. S.V. 1975. Nutrient cycles involving phosphorus and potassium on livestock farms in Northern Ireland. The Journal of Agricultural Science, Cambridge, 85, 345-349.

3. Battye R., Battye W., Overcash C., Fudge S. 1994. Development and selection of ammonia emission factors. Report No. EPA/600/R-94/190, Office of Research and Development, US Environmental Protection Agency, Washington DC.

4. Dobrzańska B., Dobrzyński G., Kiełczewski D. 2008. Deficits and water pollution. (in:) Natural environment protection. Wydawnictwo Naukowe PWN, Warszawa, 159-169. (In Polish)

5. Fotyma M., Duer I. 2006. Implementation of Nitrate Directive to Poland. Acta Agriculturae Slovenica, 87, 1, 51-58.

6. geoportal.gov.pl [access: 10.05.2016].

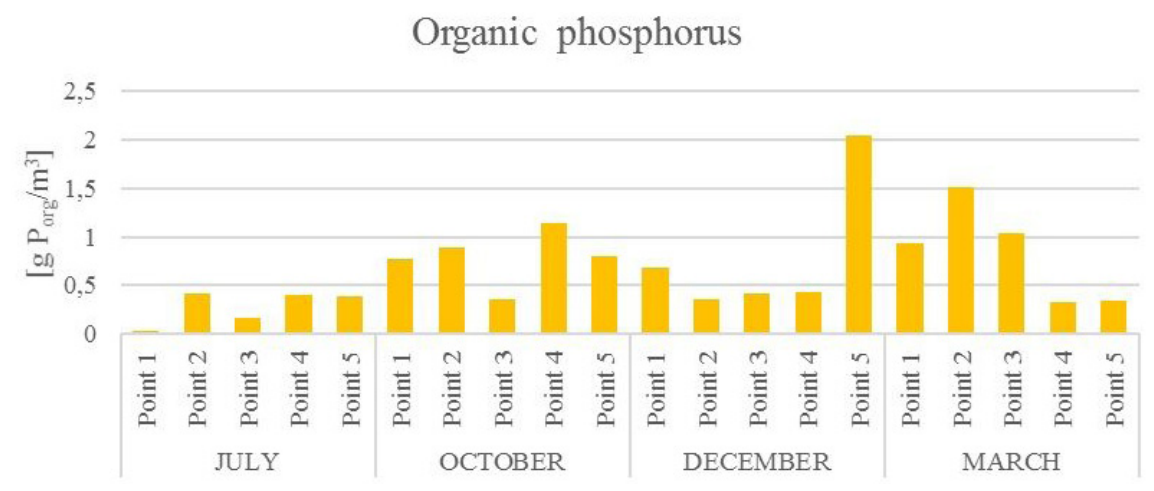

Figure 7. Seasonal changes in organic phosphorus concentration in sampling points during the researches 
7. Grabińska B, Koc J., Skwierawski A., SobczyńskaWójcik K., Rafałowska M. 2005. Concentrations and river outflow of total phosphorus from a catchment of diversified use. Ecological Engineering, 13, 87-92. (In Polish)

8. Grabińska B. 2011. River water quality changes in relations to the diversity of natural conditions and basin usage, (in:) Water resources and quality protection in rural landscape, Współczesne Problemy Kształtowania i Ochrony Środowiska, Olsztyn, 223-253. (In Polish)

9. Gundersen P., Rasmussen L. 1990. Nitrification in forest soils: effects from nitrogen deposition on soil acidification and aluminum release. Reviews in Environmental Contamination Toxicology, 113, 1-45.

10. Kiryluk A., Rauba M. 2011. Impact of agriculture on the concentration of total phosphorus in the Surface water catchment area Ślina. Ecological Engineering, 26, 122-132. (In Polish)

11. Kluczko A. 2014. Water management, operation and mainstenance manual of the retention reservoire - „Plażowy”. Preparation for B.O.S.iR., Białystok. (In Polish)

12. Koszelnik P. 2009. Sources and distribution of biogenic elements in Solina-Myczkowce retention reservoirs group. Oficyna Wydawnicza Politechniki Rzeszowskiej. (In Polish)

13. Koszelnik P., Czerwieniec E., Gruca-Rokosz R. 2014. Sanitation chemistry with analytical chemistry elements. Oficyna Wydawnicza Politechniki Rzeszowskiej, Rzeszów. (In Polish)

14. OECD 2003. Environmental Performance Reviews - Poland. Paris, France.

15. Pietrzak S., Sapek A. 1998. Ground water quality monitoring in the yard and its rural surroundings. Zeszyty Problemowe Postępów Nauk Rolniczych, z. 458, 495-504. (In Polish)

16. pogoda.interia.pl [access: 10.06.2015].

17. Rawicki K., Siwek H. 2014. Preliminary estimation of mineral nitrogen and phosphorus concentration in Surface waters in the Świdwie Lake catchment. Folia Pomeranae Universitatis Technologiae Stetiensis, Agric. Aliment. Pisc., Zootech., 309 (29), 101-114. (In Polish)
18. Rola S. 2002. The maintenance and operation manual of the Dojlidy retention reservoir. Białystok. (In Polish)

19. Sapek A. 2011. Nitrogen in atmospheric precipitation. The current state of knowledge. Woda Środowisko Obszary Wiejskie. Monograph 29, Institute of Technology and Life Science, Falenty. (In Polish)

20. Skonieczek P. 2011. Threats to water in rural areas, (in:) Water resources and quality protection in rural landscape. Współczesne Problemy Kształtowania i Ochrony Środowiska, Olsztyn, 87-107. (In Polish)

21. Strzelec M., Spyra A., Serafiński W. 2010. Biology of inland waters, Script for first and second degree biology and environmental protection students. Wydawnictwo Uniwersytetu Śląskiego, Katowice. (In Polish)

22. Szczykowska J., Siemieniuk A., Wiater J. 2015a. Diversity of the TSI indicators of the middle-forest small retention reservoir. Journal of Ecological Engineering, 16 (5), 54-61.

23. Szczykowska J., Siemieniuk A., Wiater J. 2015 b. Operating difficulties of small water reservoir located in Wasilków. Journal of Ecological Engineering, 16 (1), 122-126.

24. Szymczyk S. 2011. Zagroda wiejska jako źródło zanieczyszczenia wód, (in:) Water resources and quality protection in rural landscape. Współczesne Problemy Kształtowania i Ochrony Środowiska, Olsztyn, 107-121. (In Polish)

25. Tyszewski S., Kardel I. 2009. The Biała River valley hydrographic study. UM w Białymstoku, Białystok. (In Polish)

26. Wetzel R. G. 2001. Lomnology lake and river ecosystem. Academic Press, USA, 205-220.

27. Zdanowicz A. 2009. Water quality characteristics, (in:) Water resources and quality protection in rural landscape. Red. Mioduszewski M., Dembek W. Wydawnictwo IMUZ. Falenty, Warszawa, 58-80. (In Polish)

28. Zhou Q. X., Gibson C. E., Foy R. H. 2000. Longterm changes of nitrogen and phosphorus loadings to a large lake in north-west Ireland. Water Research, 34 (3), 922-926. 